\title{
Learning Strategy Equalizing Students’ Achievement, Metacognitive, and Critical Thinking Skills
}

\author{
Siti Ramdiah" ${ }^{1}$, A. Duran Corebima ${ }^{2, *}$ \\ ${ }^{1}$ Majoring in Biology Education, College of Teacher Training and Pedagogy -Persatuan Guru Republik Indonesia Banjarmasin, \\ Indonesia \\ ${ }^{2}$ Faculty of Natural Science and Mathematics, State University ofMalang, Indonesia \\ *Corresponding author: durancorebima@yahoo.com
}

Received June 16, 2014; Revised July 17, 2014; Accepted July 21, 2014

\begin{abstract}
Biological development difference related to gender causes significance differences including academic achievement, metacognitive, and critical thinking skills. Therefore, the learning process should be designed based on the students' learning style to equalize the students' achievement and other skills between the two genders. The purpose of this study is to find out the appropriate learning strategy that can enhance and equalize the male and female students' achievement, metacognitive, and critical thinking skills. The study had been carried out in QuasiExperiment of Pretest - Posttest Nonequivalent Control Group design. Population of the study was second grade of Banjarmasin senior high school students Indonesia majoring in science. The results of the study showed that the students' learning achievement, metacognitive, and critical thinking skills are similar or almost similar between the two genders, when the PQ4R strategy combined with the concept mapping strategy was applied.
\end{abstract}

Keywords: learning strategy, gender, achievement, metacognitive skills, and critical thinking skills

Cite This Article: Siti Ramdiah, and A. Duran Corebima, "Learning Strategy Equalizing Students' Achievement, Metacognitive, and Critical Thinking Skills." American Journal of Educational Research, vol. 2, no. 8 (2014): 577-584. doi: 10.12691/education-2-8-3.

\section{Introduction}

Along with the complexity of development and the demands of society, the quality of human resource must be improved. Related to education, the quality parameter can be measured based on the academic achievement of the students. The quality of academic performance can be obtained if the students are able to control their cognitive processes continuously. The cognitive processes control might be different from one student to another, especially when gender is involved. The difference of biological development, related to gender, seemed to be the reason of the difference related to information processing manner. Thus, it might affect the female and male students' learning style. In general, there are some differences related to gender affecting the students' learning [22]. The differences, physically, can be observed from the brain anatomy of female and male students, and this difference affects the patterns of learning and the brain activity of human from the very beginning [17]. Whereas, the issue of gender differences in intelligence or in the academic achievement has been debated for centuries and be more and more crucial since the early 1970s [36]. Furthermore, it has been known too that there was a difference between the gender, especially in learning ability and intellectual ability [35]. Various psychological research focused on aspects of behavior, moral awareness, emotional tendencies, and gender showed significant differences.
Some research related to gender explain that the differences between gender cause gap in the academic achievement. Compared to female students, male students usually have more problems in learning, especially in terms of language learning [32]. Another fact is that male students tend to get lower rank and left behind. Female students are known to be more verbalistic and have more vocabularies, including infrequently in making mistakes on language. When female students grow up, they show faster ability in reading and infrequently having difficulties in learning [30]. In addition, the Organization for Economic Co-operation and Development (OECD) recently released its three-year study of knowledge and skills of males and females in 35 industrialized countries (including the United States, Canada, the European countries, Australia, and Japan). Girls outperformed boys in every country. The statistics that brought the male scores down most significantly were their reading/writing scores [16]. Compared to female students, more male students took remedial classes [32]. In addition, the gender differences have been found in some metacognitive components, as more female students showed higher levels in self-regulation compared to male students of eleventh grade [42]. Besides, female students were able to optimize their metacognitive skill rather than their counterparts [25].

Based on some of the classic indicators of quality including literacy achievement in biology at the national, regional, and international scale, the quality of biology mastery among senior high school students was 
considered low. Other indicators were the lack of student ability to think as well as many students felt difficult in comprehending the biology contextual problems, requiring understanding, reflective, critical, and analytical thinking [29]. This phenomenon occurs in eleventh grade of senior high schools in Banjarmasin Indonesia majoring science. A piece of information obtained from one of printed media in Banjarmasin showed that teachers sometimes skipped the material since they did not master [3]. Furthermore it was also found that $82.62 \%$ of senior high school students in Banjarmasin failed at the try out in 2012 [26]. The low quality of the biology learning outcome of senior high school students had become the public attention, especially in Banjarmasin, which was considered as an educational barometer for other areas around [23].

The learning quality of female and male students in senior high school level, especially in biology, in the national scope and in Banjarmasin region, of course is not similar. Some improvements must be carried out related to the learning program involving the process of learning in order to create the gender equality. This is related to the planning of the lesson that should consider the balance need of the students in term of the academic achievement, as well as general skills such as metacognitive skills and critical thinking skills. The planning must be prepared and written based on the students' learning style because the learning process should be done in the same period. The equality of learning achievement and other skills is important because it is related to the gender opportunities and income at work [34]. Furthermore, the equality of education achievement means that both female and male students have the same opportunity to be succeeding [40]. Thus, in order to achieve gender equality a curriculum needs to be well-developed and equipped to indicate the balance of the students' academic achievement [38]. The curriculum and the learning materials should concern more to the gender, so that activities and instructional strategies will support the female and male students in developing their interests, talents, and abilities. Therefore, teachers should encourage the students to participate actively so that they might be motivated during the learning process. The learning process is developed in order to affect the students' think ability, which then it might improve their academic achievement.

The significant improvement of thinking ability is a best effect of learning. The learning is a connected thinking process named teaching of thinking, meaning that it is aimed to develop a certain mental skill, such as critical thinking skill and metacognitive skill [10]. A metacognitive skill is a kind of thinking skill related to the way ones' thinking, knowing something known and unknown. The metacognitive skill might help the students to be self-regulated learners who are responsible to the self-learning improvement and adapt their own learning strategy to reach the goals [9]. The critical thinking is a skill of making rational decision towards something believed and done [28].

The above-mentioned problems are mostly related to the application of learning strategies implemented by the biology teacher at the senior high school in Banjarmasin. The instructional strategies implemented by the teacher are the conventional strategies so those conditions influence the quality of learning and caused the students' achievement go down. In fact, most students have a very low thinking abilities which can be seen from the way they read, listen, formulate questions, create questions, answer their own question, correct answers, and write a summary. The improvement of the academic achievement between genders can be done by applying the appropriate learning strategies that might enhance their thinking skills, such as Preview, Question, Read, Reflect, Recite, and Review (PQ4R) and concept mapping. The PQ4R strategy contains some thinking process stages; so does the concept mapping strategy. It works based on the pattern of a mind map towards a material so that the information can be preserved in the long term memory. As it has been argued that the information processing involves all the cognitive activity [33]. The PQ4R strategy combined with the concept mapping strategy is potentially encouraged the students to read and comprehend the connection among concepts. Thus, the combination of the two strategies is expected to equalize both the female and male students' academic achievement as well as their other skills. This study is aimed to find out the appropriate strategies that can improve and equalize the academic achievement of the female and male students, as well as their metacognitive and critical thinking skills.

\section{Literature Review}

\subsection{Preview, Question, Read, Reflect, Recite, and Review (PQ4R) Learning Strategy}

PQ4R learning strategy is the improvement result of the SQ3R (Survey, Question, Read, Recite, and Review) learning strategy developed by Thomas and Robinson in 1972. This strategy is applicable for teaching reading and processing the learning material maximally. The steps of the PQ4R consist of Previewing, Questioning, Reading, Reflecting, Reciting, and Reviewing [5]. The strategy was effective for the students in higher level of education since it enable the students to be more focus on the meaningful information collection and they could involve themselves in creating questions, explaining, and reinvestigate the information [36]. This could show the process of describing more details of the scheme on human's brain so the new information could be recalled and learnt so that the learning is more meaningful. Reading was aimed to activate the working memory. Comprehension reading was a complex process that involved not only reading itself but also learning. A raised question might stimulate a person to find the answer; writing a question could also centralise a person's attention towards the next information and activated the working memory (WM) [41].

PQ4R learning strategy consist of several stages, named preview where the students have to scan the reading material to find the generic structure and the topics and subtopics; the students should pay attention to the title, the subtitle, and the identification found. The next stage is question refers to the self-questioning related to the material by using question word, such as what, who, where, when, why, and how. The third stage is read which refers to the activity of reading comprehensively; the students might try to answer their own questions. Reflection refers to comprehend the information obtained from the reading activities by (1) connecting every piece of information from all students; (2) connecting the 
subtopic of the reading text to the main concept; (3) solving the contradiction; and (4) answering the risen questions related to the text. Recite means that the students have to recall the information. Review means that the students have to reinvestigate the learning material, focusing on the self-questioning, and they can re-read the text if necessary [36].

\subsection{Concept Mapping}

Concept mapping can facilitate the meaningful learning since it might function as the template that helps to organize the knowledge and its structure, as well as long term retention [27]. A meaningful learning might happen if the students are able to associate the new knowledge with the relevant concept and proposition known. The link among concepts is revealed through the hierarchical structure in order to develop the relation of the related concepts in a correct order. The concept mapping has been implemented to help the students developing and organizing their basic knowledge of a particular topic. Furthermore, the concept mapping helps the students to construct the concept of "how to learn" which then facilitate them to realize the knowledge structure. The concept mapping might bring a positive effect on the teaching and learning activity because it affects the students' achievement, such as bring the high retention, applicative concepts, and concept understanding [24].

Teachers can employ the concept mapping to prepare the lesson plan, learning material, and leaning media [2]. Concept mapping is expected to help the students to solve the problems related to the complex biology discipline by integrating it to the well-structured cognitive framework. Furthermore the concept mapping is considered as a good learning strategy in terms of helping the low academic students to improve their learning achievement.

\subsection{Gender}

The term of gender refers to the dimension of psychology and socio-culture of female and male. The role of gender is related to the way of female and male to think, act, and feel [32]. The different learning styles between the female and male are deemed to influence their learning style including the metacognitive aspects as the basic of other cognitive abilities [17].

Based on the investigation done by Sear, female students develop their self-control earlier than male students [35]. Various research uncover that from the early childhood female student aware of their responsibility especially for the interpersonal interaction which might give benefit for them. Unluckily, male students seem miss this awareness. Another fact explains that female students show a low performance at mathematics [20]. A study shows that a report percentage of mathematics and science achievements of male students are higher than the achievements of female students [37]. On the other hand, female students perform better at science and technology [13]. Based on the OECD report [28], it is conveyed that the performance of the female and male students in the developing country (Russia, Brazil, and Indonesia) especially at different disciplines is vary; female students of higher school perform better at reading, while male students achieve better at mathematics. Moreover based on the research findings of Ajaja [1] it is revealed that most female students apply for the bachelor study program majoring biology, while male students dominate the physics study program, and the same number of applicant is found at chemistry study program. It is also stated that female students are likely better than male students from their early childhood.

\section{Method}

The study had been carried out in pretest-postest nonequivalent control group design. The learning strategies used during the experimentation were PQ4R strategy, concept mapping strategy, PQ4R strategy combined with concept mapping strategy, and conventional strategy. This study examined the effect of the four learning strategies on the metacognitive skill, critical thinking ability, concept gaining, and its retention of the eleventh grade of female and male students in Banjarmasin. The study had been carried out in a 4 x 2 factorial design (Figure 1).

\begin{tabular}{|c|c|c|c|c|c|}
\hline \multirow{4}{*}{ Gender $(\mathrm{G})$} & & \multicolumn{5}{|c|}{ Learning Strategy $(\mathrm{S})$} \\
\cline { 2 - 6 } & & $\mathrm{PQ} 4 \mathrm{R}\left(\mathrm{S}_{1}\right)$ & Concept Mapping $\left(\mathrm{S}_{2}\right)$ & PQ4R combined with Concept Mapping $\left(\mathrm{S}_{3}\right)$ & Conventional $\left(\mathrm{S}_{4}\right)$ \\
\cline { 2 - 6 } & Male $\left(\mathrm{G}_{1}\right)$ & $\mathrm{G}_{1} \mathrm{~S}_{1}$ & $\mathrm{G}_{1} \mathrm{~S}_{2}$ & $\mathrm{G}_{1} \mathrm{~S}_{3}$ & $\mathrm{G}_{1} \mathrm{~S}_{4}$ \\
\cline { 2 - 7 } & Female $\left(\mathrm{G}_{2}\right)$ & $\mathrm{G}_{2} \mathrm{~S}_{1}$ & $\mathrm{G}_{2} \mathrm{~S}_{2}$ & $\mathrm{G}_{2} \mathrm{~S}_{3}$ & $\mathrm{G}_{2} \mathrm{~S}_{4}$ \\
\hline
\end{tabular}

Figure 1. The 4 x 2 Factorial Design

The population of the study were all senior high school (SMA) in Banjarmasin. After the homogeneity test was done, the chosen samples were female and male students of SMA Negeri 12 Banjarmasin as the control group which then was treated by conventional strategy. The experimental groups were the students of SMA PGRI 4 Banjarmasin and SMA PGRI 7 Banjarmasin treated by PQ4R strategy, SMA Negeri 10 Banjarmasin treated by concept mapping strategy, and SMA Negeri 13 Banjarmasin treated by PQ4R strategy combined with concept mapping strategy. The total samples of the study were 96 students, consisting of 48 male students and 48 female students. There were 12 male students and 12 female students involved in each of the four groups studied.
The independent variable of the study was the learning strategy, while the dependent variables of the study were the metacognitive skill, the critical thinking skill, the cognitive learning result, and its retention related to biology. The teaching material applied in the study covers: plants and animal's tissue, musculoskeletal system, and circulatory system. The data were measured by an integrated essay test to measure the metacognitive skills, the critical thinking skills, the biology cognitive learning results, and the retention of eleventh grade students. The test was developed based on the biology basic competence for eleventh grade students as mentioned above. The retention test was done two weeks after the treatments were given. The scoring rubric of the metacognitive skill was adapted from Corebima [8] with 0 - 7of range score. 
Meanwhile, the scoring rubric of the critical thinking skill, the cognitive learning result, and the retention were adapted from Hart [19] with 0 - 4 of range score where each variable was described differently. Before the data analysis conducted by using Anacova, the assumption test were done, including normality testing and homogeneity testing.

\section{Result}

The data used in this study was obtained from the results of pretest, postest, and retention test. All the test items have been fulfilled the validity. The result of the reliability test showed that the items employed in the essay test have a high reliability index, which is 0.870 . The hypothesis testing was done by employing Anacova with significant value of 5\%. Before the hypothesis testing carried out, the data were analysed by using normality testing of One-Sample Kolmogorov-Smirnov Test and homogeneity testing of Levene's Test of Equality of Error Variances. The results of the tests showed that the data were normally distributed and almost all the variances were homogeneous. All the normality testing results are presented on Table 1 . All the homogeneity testing results are presented on Table 2 .

Table 1. The Summary of All The Normality Testing

\begin{tabular}{|c|c|c|}
\hline Data Groups & N & Sig \\
\hline Pretest of cognitive learning result & 96 & 1,676 \\
\hline Postest of cognitive learning result & 96 & 0,738 \\
\hline Pretest of metacognitive skills & 96 & 0,843 \\
\hline Postest of metacognitive skills & 96 & 0,586 \\
\hline Pretest of critical thinking skills & 96 & 2,950 \\
\hline Postest of critical thinking skills & 96 & 0,883 \\
\hline Retention & 96 & 0,681 \\
\hline
\end{tabular}

Table 2. The Summary of All The Homogeneity Testing

\begin{tabular}{|c|c|c|}
\hline Data Groups & Levene's Test Value & Sig \\
\hline Pretest of cognitive learning result & 0,950 & 0,470 \\
\hline Postest of cognitive learning result & 1,898 & 0,079 \\
\hline Pretest of metacognitive skills & 0,893 & 0,515 \\
\hline Postest of metacognitive skills & 0,798 & 0,591 \\
\hline Pretest of critical thinking skills & 0,837 & 0,560 \\
\hline Postest of critical thinking skills & 2,004 & 0,063 \\
\hline Retention & 1,198 & 0,312 \\
\hline
\end{tabular}

The summary of the Anacova result of metacognitive skill related to the interaction of the learning strategies and gender is displayed on Table 3 and Table 4. The result of the size effect test is presented on Table 5.

Table 3. Summary of ANCOVA test results on the effect of learning strategy on metacognitive skills

\begin{tabular}{|c|c|c|c|c|}
\hline $\begin{array}{c}\text { Source } \\
\end{array}$ & $\mathrm{df}$ & Mean Square & $\mathrm{F}$ & Sig. \\
\hline Pretest Metacognitive Skills & 1 & 121.178 & 7,06 & 0,009 \\
\hline Learning Strategy & 3 & 122.743 & 7,152 & 0,000 \\
\hline Gender & 1 & 71.818 & 4,185 & 0,044 \\
\hline Learning Strategy * Gender & 3 & 3.474 & 0,202 & 0,894 \\
\hline
\end{tabular}

Table 4. Comparison of mean corrected interaction related metacognitive skills between learning Strategy and gender

\begin{tabular}{|c|c|c|c|c|c|}
\hline Learning Strategy & Pretest & Postest & difference & Cor & Notation \\
\hline Conventional Male & 17,9867 & 41,5992 & 23,61 & 41,7210 & $\mathrm{a}$ \\
\hline Conventional Female & 19,4142 & 44,5758 & 25,16 & 44,3280 & $\mathrm{ab}$ \\
\hline PQ4R Male & 17,2117 & 45,7342 & 28,52 & 46,0570 & $\mathrm{ab}$ \\
\hline Concept mapping Male & 19,3258 & 46,5150 & 27,19 & 46,2900 & $\mathrm{ab}$ \\
\hline PQ4R+Concept mapping Male & 18,0808 & 47,6375 & 29,56 & 47,7350 & $\mathrm{~b}$ \\
\hline PQ4R Female & 18,8317 & 47,6875 & 28,86 & 47,5910 & $\mathrm{~b}$ \\
\hline Concept mapping Female & 17,0817 & 47,9292 & 30,85 & 48,2860 & $\mathrm{~b}$ \\
\hline PQ4R+Concept mapping Female & 19,7292 & 48,8650 & 29,14 & 48,5360 & $\mathrm{~b}$ \\
\hline
\end{tabular}

Table. 5 Computation result of size effect for ANCOVA tests

\begin{tabular}{ccc}
\hline Source & Eta squared (n2) & Effect Size \\
\hline Learning Strategy & 0.19 & Medium \\
Gender & 0.04 & Small \\
Learning Strategy * Gender & 0.01 & Small \\
\hline
\end{tabular}

Based on Table 3 and Table 4 it can be seen that the interaction effect of the learning strategies and gender on the metacognitive skill is not significant even though the effects of the learning strategies and gender are significant. Related to the interaction effect, although it's effect is not significant, the Least Significance Difference (LSD) test was done too to show the position of the combination group. The result of the LSD test reveal that the achievement of female and male students experiencing PQ4R strategy combined with concept mapping strategy is inclined higher than others although it is not significant.
Table 5 shows that the size effect criteria of the gender as well as of the interaction between the learning strategies and gender are small.

The summary of the Anacova result of the student critical thinking skill related to the interaction of the learning strategies and gender is displayed on Table 6 and Table 7. The result of the size effect test is showed on Table 8.

Table 6. Summary of test results ANCOVA effect learning strategy on critical thinking

\begin{tabular}{|c|c|c|c|c|}
\hline Source & df & Mean Square & F & Sig. \\
\hline Pretest Critical Thinking & 1 & 201.654 & 4,068 & 0,047 \\
\hline Learning Strategy & 3 & 695.728 & 14,035 & 0,000 \\
\hline Gender & 1 & 507.063 & 10,229 & 0,002 \\
\hline Learning Strategy * Gender & 3 & 78.705 & 1,588 & 0,198 \\
\hline
\end{tabular}

Table 7. Comparison of mean corrected interaction related critical thinking between learning strategy and gender

\begin{tabular}{|c|c|c|c|c|c|}
\hline Learning Strategy & Pretest & Postest & difference & Cor & Notation \\
\hline Conventional Male & 27,7767 & 43,5767 & 15,80 & 43,646 & $\mathrm{a}$ \\
\hline Conventional Female & 28,7317 & 44,3583 & 15,63 & 44,021 & $\mathrm{ab}$ \\
\hline PQ4R Male & 26,9100 & 48,9583 & 22,05 & 49,397 & abc \\
\hline Concept mapping Male & 27,6908 & 50,0000 & 22,31 & 50,106 & abc \\
\hline PQ4R+Concept mapping Male & 27,7775 & 52,0833 & 24,31 & 52,153 & abc \\
\hline PQ4R Female & 27,2567 & 52,9517 & 25,70 & 53,243 & bcd \\
\hline Concept mapping Female & 28,6467 & 55,5575 & 26,91 & 55,257 & $\mathrm{~cd}$ \\
\hline PQ4R+Concept mapping Female & 28,7325 & 61,6325 & 32,90 & 61,295 & $\mathrm{~d}$ \\
\hline
\end{tabular}


Table 8. Computation result of size effect for ANCOVA tests

\begin{tabular}{|c|c|c|}
\hline Source & Eta squared (n2) & Effect Size \\
\hline Learning Strategy & 0.31 & Large \\
\hline Gender & 0.10 & Medium \\
\hline Learning Strategy * Gender & 0.05 & Small \\
\hline
\end{tabular}

Based on Table 6 and Table 7 it can be seen that the effect of the interaction of the learning strategies and gender on the critical thinking skill is not significant but the effects of the learning strategies and gender are significant. The Least Significant Difference (LSD) test is also done to show the position of the combination group although the effect of interaction is not significant. The result of the Least Significant Difference test reveals that the achievement of female and male students experiencing PQ4R strategy combined with concept mapping strategy is inclined higher than others although it is not significant. Table 8 shows that the gender size effect criteria are medium while the size effect of interaction between learning strategies and gender is small.

The summary of the Anacova result of the student cognitive learning result related to the interaction of the learning strategies and gender is displayed on Table 9 and Table 10. The result of the size effect test is showed on Table 11.

Table 9. Summary of test results ANCOVA effect learning strategy on cognitive learning result

\begin{tabular}{|c|c|c|c|c|}
\hline Source & df & $\begin{array}{c}\text { Mean } \\
\text { Square }\end{array}$ & F & Sig. \\
\hline $\begin{array}{c}\text { Pretest Cognitive Learning } \\
\text { Result }\end{array}$ & 1 & 1,099 & 0,018 & 0,893 \\
\hline Learning Strategy & 3 & 491,337 & 8,133 & 0,000 \\
\hline Gender & 1 & 289,561 & 4,793 & 0,031 \\
\hline Learning Strategy * Gender & 3 & 29,216 & 0,484 & 0,695 \\
\hline
\end{tabular}

Table 10. Comparison of mean corrected interaction related cognitive learning result between learning strategy and gender

\begin{tabular}{|c|c|c|c|c|c|}
\hline \multicolumn{1}{|c|}{ Learning Strategy } & Pretest & Postest & difference & Cor & Notation \\
\hline Conventional Male & 27,8650 & 43,1425 & 15,28 & 43,119 & $\mathrm{a}$ \\
\hline Conventional Female & 28,7342 & 45,2267 & 16,49 & 45,164 & $\mathrm{a}$ \\
\hline PQ4R Male & 25,6942 & 50,3475 & 24,65 & 50,421 & $\mathrm{ab}$ \\
\hline Concept mapping Male & 26,8233 & 50,8700 & 24,05 & 50,893 & $\mathrm{ab}$ \\
\hline PQ4R+Concept mapping Male & 27,0842 & 51,3025 & 24,22 & 51,314 & $\mathrm{ab}$ \\
\hline PQ4R Female & 26,4767 & 51,6508 & 25,17 & 51,689 & $\mathrm{ab}$ \\
\hline Concept mapping Female & 28,0392 & 56,0767 & 28,04 & 56,045 & $\mathrm{~b}$ \\
\hline PQ4R+Concept mapping Female & 27,9533 & 57,0308 & 29,08 & 57,003 & $\mathrm{~b}$ \\
\hline
\end{tabular}

Table 11. Computation result of size effect for ANCOVA tests

\begin{tabular}{|c|c|c|}
\hline Source & Eta squared $\left(\mathrm{n}^{2}\right)$ & Effect Size \\
\hline Learning Strategy & 0.22 & Medium \\
\hline Gender & 0.05 & Small \\
\hline Learning Strategy * Gender & 0.02 & Small \\
\hline
\end{tabular}

Based on Table 9 and Table 10 it can be seen that the effect of the interaction of the learning strategies and gender on the cognitive learning result is not significant, but the effects of the learning strategies and gender are significant. The Least Significant Difference (LSD) test is also done to show the position of the combination group although the effect of interaction is not significant. The result of the LSD test reveals that the achievement of female and male students experiencing PQ4R strategy combined with concept mapping strategy is inclined higher than others although not significant. Table 11 shows that the size effect criteria of the gender as well as of the interaction between learning strategies and gender are small.

The summary of the Anacova result of the student retention related to the interaction of the learning strategies and gender is displayed on Table 12 and Table 13. The result of the size effect test is showed on Table 14 .

Table 12. Summary of test results ANCOVA effect learning strategy on retention

\begin{tabular}{|c|c|c|c|c|}
\hline Source & $\mathrm{df}$ & Mean Square & $\mathrm{F}$ & Sig. \\
\hline Pretest Retention & 1 & 3596,038 & 407,245 & 0,000 \\
\hline Learning Strategy & 3 & 366,075 & 41,457 & 0,000 \\
\hline Gender & 1 & 107,919 & 12,222 & 0,001 \\
\hline Learning Strategy * Gender & 3 & 29,108 & 3,296 & 0,024 \\
\hline
\end{tabular}

Table 13. Comparison of mean corrected interaction related retention between learning strategy and gender

\begin{tabular}{|c|c|c|c|c|c|}
\hline Learning Strategy & Pretest & Postest & difference & Cor & Notation \\
\hline Conventional Male & 43,1425 & 41,5808 & 1,56 & 47,837 & $\mathrm{a}$ \\
\hline Conventional Female & 45,2267 & 48,5258 & 3,30 & 53,058 & $\mathrm{ab}$ \\
\hline PQ4R Male & 50,3475 & 55,3817 & 5,03 & 55,678 & bc \\
\hline Concept mapping Male & 50,8700 & 56,3375 & 5,47 & 56,202 & bc \\
\hline PQ4R Female & 51,6508 & 56,4233 & 4,77 & 55,642 & bc \\
\hline PQ4R+Concept mapping Male & 51,3025 & 60,6783 & 9,38 & 60,185 & cd \\
\hline Concept mapping Female & 56,0767 & 62,5875 & 6,51 & 58,146 & $\mathrm{~cd}$ \\
\hline PQ4R+Concept mapping Female & 57,0308 & 67,0142 & 9,98 & 61,783 & $\mathrm{~d}$ \\
\hline
\end{tabular}

Table 14. Computation result of size effect for ANCOVA tests

\begin{tabular}{|c|c|c|}
\hline Source & Eta squared (n2) & Effect Size \\
\hline Learning Strategy & 0.12 & Medium \\
\hline Gender & 0.01 & Small \\
\hline Learning Strategy * Gender & 0.01 & Small \\
\hline
\end{tabular}

Based on Table 122 it can be seen that the interaction effect of the learning strategies and gender is significant. The Least Significant Difference (LSD) test of the interaction effect is showed on Table 13. The computation result showed on Table 13 reveals that the achievement of female and male students related to PQ4R learning strategy combined with concept mapping is better than achievement related to other learning strategies. Table 14 shows that both the size effect of gender as well as of the interaction between the learning strategies and gender are small. 
The result of the inferential statistics analysis related to the interaction effect of all parameters show that the achievement of female and male students experiencing PQ4R learning strategy combined with concept mapping learning strategy are inclined higher than those who were treated by using other learning strategies. The size effects of gender as well as of the interaction between the learning strategies and gender related to all parameters are ranging from small to medium.

\section{Discussion}

The findings of the study reveal that the combination of PQ4R learning strategy and concept mapping is inclined having a higher potency in enhancing the achievement of female and male students in terms of the metacognitive skill, the critical thinking ability, the cognitive learning result, and the retention. It is believed that the PQ4R learning strategy combined with concept mapping learning strategy has the appropriate learning stages needed by female and male students so that it enhances their achievement. The United States Agency for International Development [40] had declared that the quality of education should consider the need of the students. It means that all of the students, regardless the gender, should experience similar learning strategy so that the students might be able to develop better skills in every subjects taught.

The implementation of PQ4R learning strategy combined with concept mapping to female and male students contribute to the improvement of the learning result. Preview stage which is the beginning of the activity is aimed at scanning the reading text quickly and comprehending the main topic of the text [5]. Moreover question step or creating questions is important for it helps the students to focus on the text where students might identify the important information so that they can broaden their curiosity [5]. Furthermore, the successful of a particular learning involves the activity of questioning and revising [15]. Therefore, the highest attainment happened when students are able to raise questions and answer their own questions [11]. As the implementation of questioning method in class help the students to improve the content and promote their critical and analytical thinking, thus high level questions require the students to answer and analyse. Regarding this condition, evaluating information is the core purpose of the learning to encourage the students' higher level thinking skill [21].

Reading step is aimed to find out the answers of the questions. Besides, it requires the students to make the concept mapping based on the given texts. Furthermore, the meaningful learning needs three conditions, that will be described (1) the learning material should be conceptual and delivered by using clear instruction language; (2) the students have to be ready with the relevant information before the learning started; and (3) the students must be cooperative during the process of meaningful learning [27]. In addition, learning and recalling activities can be improved if the students are able to integrate the information obtained from both verbal and presentation, for example concept mapping [18]. Concept mapping strategy is used to measure students' comprehension and to identify every misconception among concepts [7]. Concept mapping is more suitable for enhancing the cognitive learning results to the level of analytical dimension [39].

Reflecting or Reciting are done by connecting and integrating the questions and answers based on the created concept mapping. These stages help the students to comprehend the contents of the text deeper. The process of deep thinking has to connect the newly collected information with the prior one and to link the concepts to the daily life [4].

Reviewing is done if there is missing information so that every students can make a good summary. This step is important [14] so the learning activity can be meaningful. Reviewing is essential since it aims to develop the metacognitive awareness, contents, and response of the students [5]. Reviewing followed by summarizing activity of reading material increases the learning achievement [12]. Information of the learning material can be obtained easily through reviewing activity so the students can retell the information through recalling activity. In addition, the summary re-reading can monitor the self-assurance and identify the aspects needed in the development of the future knowledge [5].

Reading, reflecting, and reciting stages of concept mapping strategy are the crucial stages that fulfil the need of the students. It shows that the combination of PQ4R learning strategy and concept mapping learning strategy is able to equalize the achievement of female and male students, because the characteristics of PQ4R learning strategy and the characteristics of concept mapping learning strategy complement to one another. Most female students like PQ4R learning strategy since it facilitates them with reading activity, while most male students like concept mapping learning strategy since it enables them to identify and to connect the concepts or the combination of concept mapping. Concept mapping is an effective learning strategy to help the low achievers especially those of male students, to improve their scores [6]. Moreover, it is also stated that through the implementation of concept mapping learning strategy, male students are more active in the process of relationship identification among concepts.

\section{Conclusion}

Based on the above discussion, related to the dependent variables, such as the metacognitive skill, the cognitive learning result, and the retention, the achievement of female and male students is the same. Both female and male students experiencing PQ4R learning strategy combined with concept mapping learning strategy are inclined achieving good scores than those experiencing PQ4R learning strategy, concept mapping learning strategy, and conventional learning strategy.

\section{Suggestion}

A better lesson planning is an important point in a learning activity to achieve the goals of the learning. It is suggested to teachers of senior high school level to implement PQ4R learning strategy combined with concept 
mapping learning strategy to equalize the achievement of female and male students.

\section{References}

[1] Ajaja O. P. "Unequal Achievement of Science Undergraduates: Does Sex Influence the Differences?” US-China Education Review B (6) 578-594, 2012. [Online]. Available files.eric.ed.gov.pdf. [Accessed April 25, 2013].

[2] Arslan, M. "The Influence Of Teaching Note-Taking And Information Mapping On Learning And Recalling In Science". The Turkish Online Journal of Educational Technology-TOJET vol 5 Issue 2, 2006. [Online]. Available www.tojet.net/articles/v5i2/528.pdf. [Accessed Oct 1, 2011].

[3] Banjarmasin Post. "Guru Lompat Bahan Belajar”. 2 Februari (2012). [Online]. Available http://getlocalne.ws/world/indonesiabanjarmasin/banjarmasin_post news 6404617. [Accessed February 5, 2012].

[4] Berkant, HG. “An Investigation of Students' Meaningful Causal Thinking Abilities in Terms of Academic Achievement, Reading Comprehension and Gender”. Educational Sciences: Theory \& Practice. 9 (3) 1149-1165, 2009. [Online]. Available files.eric.ed.gov.pdff. [Accessed Dec 20, 2013].

[5] Bibi, R.. Effect of PQ4R Study Strategy in Scholostic Achievement of Secondary School Student in Punjab (Pakistan).Submitted In Partial Fulfillment of The Requirements For The Degree Of Doctor Of Philosophy In Education Foundation University Islamabad, Pakistan. 2011. [Online]. Available eprints.hec.gov.pk. [Accessed Dec 15, 2013].

[6] Boujaoude, S., \& May, A. "The Effect of Using Concept Maps as Study Tools on Achievement in Chemistry".Eurasia Journal of Mathematics, Science and Technologi Education 4 (3): 233-246, 2008. Beirut Lebanon : American University of Beirut.

[7] Ching. "Using Concept Maps to Gauge Students' Understanding”. The Internet TESL Journal, Vol. X, No. 3, 2004. [Online]. Available http://iteslj.org/Techniques/Lee_ConceptMaps. [Accessed Sept 1, 2012].

[8] Corebima, A.D. "The Validation Of Metacognitive Skill Measurement Combined in Achievement Test”. Paper Presented at the $4^{\text {th }}$ Redesigning Pedagogy International Conference. Juni 2011 Singapure.

[9] Corebima, A.D. 2006. Metakognisi: Suatu Ringkasan Kajian. Paper presented at the Training Strategy Metakognitive on Learning Biology for High School Biology Teachers in Palangkaraya, August 23.

[10] Costa, A.L. The School as a Home for the Mind: Creating Mindful Curriculum, Instruction, and dialogue (second edition). Thousand Oaks: Corwin Press. 2008. [Online] Available http://books.google.co.id/books?id. [Accessed Dec 14, 2013.

[11] D’Avanzo, C. "Research on learning: Potential for improving college ecological examples”. Bioscience. 1 (10): 533-540, 2003. [Online]. Available www.frontiersinecology.org. [Accessed Oct 5, 2012].

[12] Degeng, I Nyoman Sudana. Pengorganisasian Pengajaran Berdasarkan Teori Elaborasi dan Pengaruhnya terhadap Perolehan Belajar Informasi Verbal dan Konsep. PPs UM, Malang, Indonesia: Dissertation was not published. 1988.

[13] Edokpayi \& Suleiman. "Student Combined Science Achievement as Predictor of Later Achievement in Chemistry: A case study Among Selected Secondary schools in Zaria Metropolis”. Archives of Applied Science Research. 3 (4), 2011. [Online]. Available (http://scholarsresearchlibrary.com/archive.html). [Accessed Dec 17, 2013].

[14] Eggen, P \& Kauchak, D. Strategi dan Model Pembelajaran. Mengajarkan Konten dan Keterampilan Berpikir. Translated by Satrio Wahono. Jakarta: Indeks. 2012

[15] Fisher, R. "Teaching thinking and creativity Developing creative minds and creative futures Thinking about Thinking: Developing Metacognition in Children”. This paper was first published in Early Child Development and Care Vol 141, 1-15, 1998. [Online]. Available http://www.teachingthinking.net. [Accessed Dec 20, 2013).

[16] Gurian, M., Stevens, K. "With boys and girls in mind". Educational Leadership, 62 (3), 21-26, 2004. [Online]. Available http://www.ascd.org/publications/educational-leadership /nov04/vol62/num03/With-Boys-and-Girls-in-Mind.aspx. [Accessed Feb 2, 2014].

[17] Gurian, M. Stevens K, Patricia Henley, \& Terry Trueman. 'Boys and girls learn differently! : a guide for teachers and parent”. Rev. 10th anniversary ed. Jossey-Bass A wiley Imprint. 2002. Available www.josseybass.com [Accessed Dec 20, 2013].

[18] Halpern, D.F. \& Milton, D.H. Teaching for Long Term Retention and Transfer. Applying the Science of Learning to the University and Beyond: Cognitive, Motivational, and Social Factors. 2003. [Online]. Available at berger.claremontmckenna.edu/asl. [Accessed Oct 23, 2013].

[19] Hart, D. Authentic Assesment A handbook for Educators. Addison Wesley Publishing company, California, New York, 1994. p 74.

[20] Isa, H. \& Balarabe, R. M. "Analysis of the participation and performance of males and females in Nigeria in science and technology programmes: A case study of ten years National Diploma in Nuhu Bamalli Polytechnic, Zaria”. Educational Research and Review Vol. 4 (9), 588-595, 2009. [Online]. Available http://www.academicjournals.org. [Accessed Dec 20, 2013].

[21] Jacobsen, D.A., Enggen, P., \& Kauchak, D. Method for Teaching. Metode-Metode Pengajaran Meningkatkan Belajar Siswa TKSMA. Translated by Achmad Fawaid and Khoirul Anam. Pustaka Pelajar Yogyakarta. 2009.

[22] Jensen, Eric. Brain-Based Learning. Pembelajaran Berbasis Kemampuan Otak Cara Baru dalam Pengajaran dan Pelatihan. Translated by Narulita Yusron. Pustaka Pelajar Yogyakarta, 2008.

[23] Juhrian. Keterampilan Berpikir dan Hasil Belajar melalui Penerapan Perangkat Pembelajaran Model Kooperatif Tipe STAD dengan Pendekatan Lingkungan Konsep Keanekaragam Hayati di SMA Islam Sabilal Muhtadin Banjarmasin. 2012. [Online]. Available http://propil-sains.blogspot.com. [Accessed August 23, 2013].

[24] Ling, Y., \& Hong, K.B. Concept mapping and pupils’ learning in primary science in Singapore. Asia-Pacific Forum on Science Learning and Teaching, Volume 8, Issue 2, Article 11. 2007. [Online]. Available www.ied.edu.hk/apfslt/.../v8_issue2.../lingy.pdf. [Accessed Dec 23, 2013]

[25] Mayasari, H. Kajian Tentang Pengaruh Strategi Pembelajaran PjBL (Project Based Learning) Terhadap Keterampilan Metakognitif Siswa Putra dan Putri Kelas X SMA Negeri di Malang. PMIPA UM, Malang, Indonesia: Thesis was not published. 2010.

[26] Media Kalimantan “Try Out UN SMA/MA Se-Kalsel Jeblok”. 28 Februari, 2012. [Online]. Available http://olahraga.inilah.com. [Accessed March 12, 2012].

[27] Novak, J. D. Concept Maps: What the heck is this?. Excerpted, rearranged (and annotated). Cornell University. 2008. [Online]. Available http://cmap.ihmc.us. [Accessed May 2 2013).

[28] Nur, M., Retno, P.W. \& Sugiarto, B. Teori-teori Pembelajaran Kognitif. 2008. Surabaya: Institut Keguruan dan Ilmu Pendidikan Surabaya.

[29] Paidi. Pengembangan Perangkat Pembelajaran Biologi yang Mengimplementasikan PBL dan Strategi Metakognitif serta Efektifitasnya terhadap Kemampuan Metakognitif, Pemecahan Masalah dan Penguasaan Konsep Biologi Siswa SMA di Sleman Yogyakarta.PPs UM, Malang, Indonesia: Dissertation was not published. 2008.

[30] Pasiak, Taufiq. Revolusi IQ/EQ/SQ antara Neurosains dan AlQuran. PT Mizan Pustaka, Bandung, 2005, 99-100.

[31] Report on the Gender Initiative: Gender Equality in Education, Employment and Entrepreneurship. Meeting of the OECD Council at Ministerial Level Paris, 25-26 May 2011.

[32] Santrock, J.W. Remaja. (Edition of 11). Translated by Benedictine Widyasinta. Erlangga Jakarta, 2007. 222-239.

[33] Schunk, Dale, H. Learning Theories An Educational Perspective (Sixth Edition).Translated by Eva Hamdiah and Rahmat Fajar. Teori-teori Pembelajaran Perspektif Pendidikan. Pustaka Pelajar, Yogyakarta, 2012, 229-230.

[34] Schnepf, Sylke Viola. Gender Equality in Educational Achievement: An East-West Comparison. Discussion Paper No. 1317. University of Southampton, University of Hamburg and IZA Bonn, 2004. 
[35] Setiawan, T.I.Pengaruh Strategi Instruksional dan Jenis Kelamin Mahasiswa Kedokteran Terhadap Prestasi Belajar Kode Etik Kedokteran. Jakarta: Jurusan Bimbingan dan Konseling Fakultas Ilmu Pendidikan Universitas Negeri Jakarta. 2008.

[36] Slavin. Psikologi Pendidikan teori dan Praktek. volume 1. PT Indeks, Jakarta, 2008.

[37] Thomas, J. \&Stockton, C. "Socioeconomic Status, Race, Gender, and Retention: Impact On Student Achievement”. Vol 7, 2003. [Online]. Available www.Usca.Edu/Essays/Vol72003)/stockton.pdf. [Accessed Dec 18, 2013).

[38] Thorius, Kathleen King. Gender Equity Matters! The Equity Alliance at ASU Region IX Equity Assistance Center Arizona State University. without year. [Online]. Available www.equityallianceatasu.org. [Accessed Dec 23, 2013].
[39] Tindangen, M. Implementasi Pembelajaran Kontekstual Concept mapping Biologi SMP pada Siswa Berkemampuan Awal Berbeda di Kota Malang dan Pengaruhnya Terhadap Kemampuan Berpikir Tingkat Tinggi dan Hasil Belajar Kognitif. PPs UM, Malang, Indonesia: Dissertation was not published.2006.

[40] United States Agency for International Development (USAID). “Gender Equality Framework” USAID. Washington, DC, 2008.

[41] Wong, L. Essential Study Skills. Boston, Houghton Mifflin Company. 2009. [Online]. Available http://en.bookfi.org/. [Accessed May 2, 2013].

[42] Zimmerman, B. J. and Martinez-Pons, M. 'Student differences in self-regulated learning: relating grade, gender, and giftedness to self-efficacy and strategy use". Journal of Educational Psychology 82, pp. 51-59, 1990 